\title{
PERUBAHAN SETTING RUANG DAN POLA AKTIFITAS PUBLIK DI RUANG TERBUKA KAMPUS UNISAN GORONTALO
}

\author{
Moh. Muhrim tamrin ST.,MT \\ Prodi Arsitektur, Fakultas Teknik, Universitas Ichsan Gorontalo
}

\begin{abstract}
Abstrak
Ruang terbuka publik adalah ruang tidak terbangun dalam kota yang berfungsi untuk meningkatkan kualitas estetika, lingkungan, dan kesejahteraan warganya. Ruang publik merupakan suatu ruang yang terbentuk atau didesain sehingga ruang tersebut dapat menampung sejumlah besar orang (public) dalam melakukan aktivitas-aktivitas yang bersifat publik sesuai dengan fungsi ruang publik tersebut. Manusia mempunyai kepribadian individual, tetapi manusia juga makhluk sosial yang hidup dalam masyarakat, dalam memenuhi kebutuhan sosialnya, manusia berperilaku sosial dalam lingkungannya yang dapat di amati dari fenomena perilaku-lingkungan, kelompok-kelompok pemakai, tempat terjadinya aktivitas. Fenomen ini menunjuk pada pola-pola perilaku pribadi, yang berkaitan dengan lingkungan fisik yang ada dalam hal ini taman kota, perilaku interpersonal manusia meliputi ruang personal (personal space), teritorialitas (territoriality), kesesakan dan kepadatan (crowding and density), dan privasi (privacy) Universitas Ichsan (Unisan) Gorontalo merupakan salah satu Universitas di kota Gorontalo yang dimana aktifitas yang terjadi hampir tiap saat, selain sebagai tempat menuntut ilmu, kampus Unisan biasanya digunakan oleh mahasiswa untuk berkumpul di area ruang terbuka kampus Unisan. Penelitian ini bertujuan mengetahui Perubahan setting ruang publik di kampus Unisan Gorontalo. Serta Untuk mengetahui pola aktifitas pengguna ruang terbuka kampus Unisan Gorontalo. Dari hasil yang diperoh terlihat adanya perubahan setting ruang terbuka publik di area kampus unisan.
\end{abstract}

Kata kunci: Setting Ruang, Pola Aktifitas, Unisan.

\begin{abstract}
Public open space is a unbuilt space in the city that serves to improve the aesthetic quality, environment, and welfare of its citizens. Public space is a space that is formed or designed in such a way that the space can accommodate a large number of people (public) in carrying out activities that are public in accordance with the function of the public space. Humans have individual personalities, but humans are also social beings who live in society, in meeting their social needs, humans behave socially in their environment that can be observed from the behavioral-environmental phenomenon, user groups, the place where activities occur. This phenomenon refers to patterns of personal behavior, which are related to the physical environment in this city park, human interpersonal behavior includes personal space, teritoriality, crowding and density, and privacy. Ichsan University (Unisan) Gorontalo is one of the universities in Gorontalo City where activities occur almost every time, not only as a place of study, Ichsan University also usually used by students to gather in the open space area of Unisan campus. This study aims to find out the changes in the setting of public spaces at the Unisan Gorontalo campus. And to find out the pattern of activity of open space users of Unisan Gorontalo campus. According to the final result, there is a change in the public open space setting in the Unisan campus area.
\end{abstract}

\section{PENDAHULUAN}

Ruang publik/ public space merupakan suatu ruang yang terbentuk atau didesain sedemikian rupa sehingga ruang tersebut dapat menampung sejumlah besar orang (public) dalam melakukan aktivitasaktivitas yang bersifat publik sesuai dengan fungsi ruang publik tersebut. Respon seseorang terhadap lingkungan bergantung pada bagaimana individu yang bersangkutan mempersepsikan lingkungannya. Salah satu hal yang dipersepsikan manusia tentang lingkungannya adalah ruang di sekitarnya, baik ruang natural maupun ruang buatan.

Manusia dan lingkungan memiliki hubungan yang tidak dapat terpisahkan, Lingkungan mempengaruhi sifat dan perilaku manusia, demikian pula manusia akan mempengaruhi lingkungan
akan tempat hidupnya. Selain menjadi wadah manusia beraktivitas, lingkungan juga menjadi bagian dari pola perilaku manusia, hal ini bisa di lihat dari salah satu penggunaan taman sebagai wadah bersosialisasi masyarakat, bagaimana manusia saling berbagi ruang dengan sesamanya.

Aspek sosialnya adalah bagaimana manusia berbagi dan membagi ruang dengan sesamanya. Manusia mempunyai kepribadian individual, tetapi manusia juga makhluk sosial yang hidup dalam masyarakat, dalam memenuhi kebutuhan sosialnya, manusia berperilaku sosial dalam lingkungannya yang dapat di amati dari fenomena perilakulingkungan, kelompok-kelompok pemakai, tempat 
terjadinya aktivitas. Fenomen ini menunjuk pada pola-pola perilaku pribadi, yang berkaitan dengan lingkungan fisik yang ada dalam hal ini Kawasan Ruang Terbuka Kampus Universitas Ichsan Gorontalo, perilaku interpersonal manusia meliputi ruang personal (personal space), teritorialitas (territoriality), kesesakan dan kepadatan (crowding and density), dan privasi (privacy) (Laurens, 2004).

Perguruan Tinggi atau biasa disebut dengan istilah populer "kampus" dapat menjadi bagian utama dari sebuah masyarakat perkotaan. Bahkan terkadang, dapat memberikan ciri khas tersendiri terhadap lingkungan kotanya. Masing-masing kelompok dari elemen perguruan tinggi tersebut akan saling bekerja sama mendukung kegiatan akademik yang kondusif dengan melakukan tugasnya masing-masing. Dengan berbagai fasilitas yang disediakan oleh pihak Perguruan Tinggi, maka mahasiswa pun secara tidak langsung berkewajiban untuk turut menjaga berbagai fasilitas yang ada agar segala kegiatan tetap berlangsung dengan baik dan fasilitas tersebut masih dapat digunakan lagi untuk mahasiswa baru yang selanjutnya akan masuk.

Universitas Ichsan (Unisan) Gorontalo merupakan salah satu Universitas di kota Gorontalo yang dimana aktifitas yang terjadi hampir tiap saat, selain sebagai tempat menuntut ilmu, kampus Unisan biasanya digunakan oleh mahasiswa untuk berkumpul di area ruang terbuka kampus Unisan.

\section{ISI PENELITIAN}

Penelitian ini merupakan penelitian kualitatif dengan pendekatan rasionalistik, yaitu penelitian yang hanya untuk menggambarkan, menjelaskan, atau meringkas berbagai kondisi, situasi, atau fenomena menurut kejadian sebagaimana adanya yang dapat dipotret, diwawancara, diobservasi, serta yang dapat diungkapkan melalui bahan-bahan dokumenter.

Penelitian kualitatif adalah penelitian yang memiliki tingkat kritisme yang lebih dalam semua proses penelitian. Ada tiga alasan penelitian kualitatif dengan pendekatan rasionalistik di gunakan, yaitu: (1) karakteristik pola Perilaku mahasiswa di lokasi penelitian adalah heterogen, (2) populasi mahasiswa yang menggunakan ruang terbuka kampus Unisan tidak diketahui, (3) penelitian ini tidak bertujuan untuk membuktikan hipotesis, Cara penelitian dimulai dengan penentuan lokasi penelitian, penentuan kasus taman dan responden, cara pengumpulan dan pencatatan data, cara analisis, dan langkah terakhir adalah pembahasan hasil penelitian dan kesimpulan.

Penelitian ini dilaksanakan selama 3 bulan. Kegiatan yang dilakukan adalah pengambilan gambar, tanya jawab dengan responden, dan melakukan pengamatan langsung ke lokasi pengamatan, Penelitian ini dilakukan di ruang terbuka kampus Unisan. Waktu penelitian yang digunakan adalah pagi, siang, sore dan malam hari dengan durasi waktu 2 jam tiap waktunya, untuk melihat pola aktivitas mahasiswa dalam memanfaatkan waktu dan tempat tertentu di dalam ruang terbuka kampus Unisan.

Data yang diperoleh dianalisis kemudian disajikan secara deskriptif kualitatif, yaitu menjelaskan, menguraikan, dan menggambarkan sesuai dengan Judul yang diteliti, Untuk mendapatkan data yang dibutuhkan, maka teknikteknik analisis data yang dilakukan setelah pengumpulan data adalah: (1) Reduksi data, menyatukan data-data hasil observasi aktivitas pengguna Taman Macan disusun lebih sistematis, sehingga mudah dipahami. (2) Penyajian data, yaitu usaha untuk menunjukkan sekumpulan data atau informasi, untuk melihat gambaran keseluruhannya atau bagian tertentu dari penelitian tersebut. (3) Kesimpulan, merupakan proses untuk menjawab permasalahan dan tujuan sehingga ditentukan saran dan masukan untuk pemecahan masalah.

\subsection{Gambaran Ruang Terbuka Kampus Unisan}

Kampus baru Universitas Ichsan didirikan pada tahun 2005, di atas lahan seluas $11.000 \mathrm{M}^{2}$, kampus baru unisan berada di jalan ahmad najamudin. Di sekitar site kampus Unisan berbatasan dengan universitas terbuka, Kantor Bulog, Kantor PDAM, Kantor Kppn.

Sesuai dengan penetapan judul yang berlokasi dikampus Universitas Icsan Gorontalo, dimana fokus penelitian lebih dititik beratkan pada ruangruang terbuka kampus, dalam hal ini adalah area sekitar bangunan utama kampus Unisan

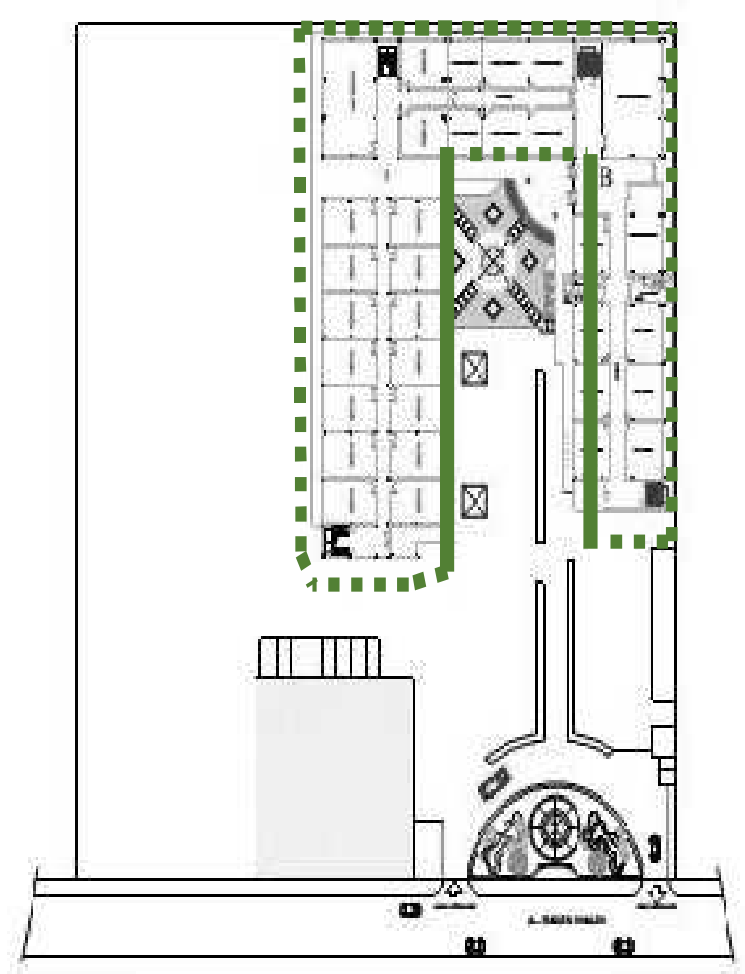

Gambar. 1 Site Plan Univrsitas Ichsan Gorontalo 
Seseorang akan tertarik dan bertahan di suatu tempat jika di tempat tersebut terdapat orang lain. Ketertarikan ini kemudian membentuk pola aktivitas di ruang publik (Whyte 1980), Respons seseorang terhadap lingkungan bergantung pada bagaimana individu yang bersangkutan mempersepsikan lingkungannya, salah satu hal yang dipersepsikan manusia tentang lingkungannya adalah ruang di sekitarnya, baik ruang natural maupun ruang buatan, aspek sosialnya adalah bagaimana manusia berbagi dan membagi ruang dengan sesamanya (Laurens, 2004). Proses sosial dalam pola perilaku mahasiswa dalam memanfaatkan ruang terbukia kampus Unisan,

\subsection{Pola Aktifitas Mahasiswa Dalam Memanfaatkan Ruang Terbuka Kampus Unisan}

a. Ruang personal (personal space)

Ruang personal merupakan suatu area dengan batas maya yang mengelilingi diri seseorang dan orang lain tidak diperkenankan masuk ke dalamnya (Laurens, 2004). Ruang personal (personal space), berupa domain kecil sejauh jangkauan manusia yang di miliki setiap orang. Edward Hall berpendapat bahwa ruang personal adalah suatu jarak berkomunikasi, dimana jarak antarindividu ini adalah juga jarak berkomunikasi. Dalam pengendalian terhadap gangguan-gangguan yang ada, manusia mengatur jarak personalnya dengan pihak lain (Laurens 2004). Besar atau kecilnya jarak personal seseorang dengan orang lain dipengaruhi oleh jenis kelamin dan umur, pada hasil survei terlihat area di sekitar kantor pengelola lebih terlihat jarak personal antar laki-laki dan perempuan.
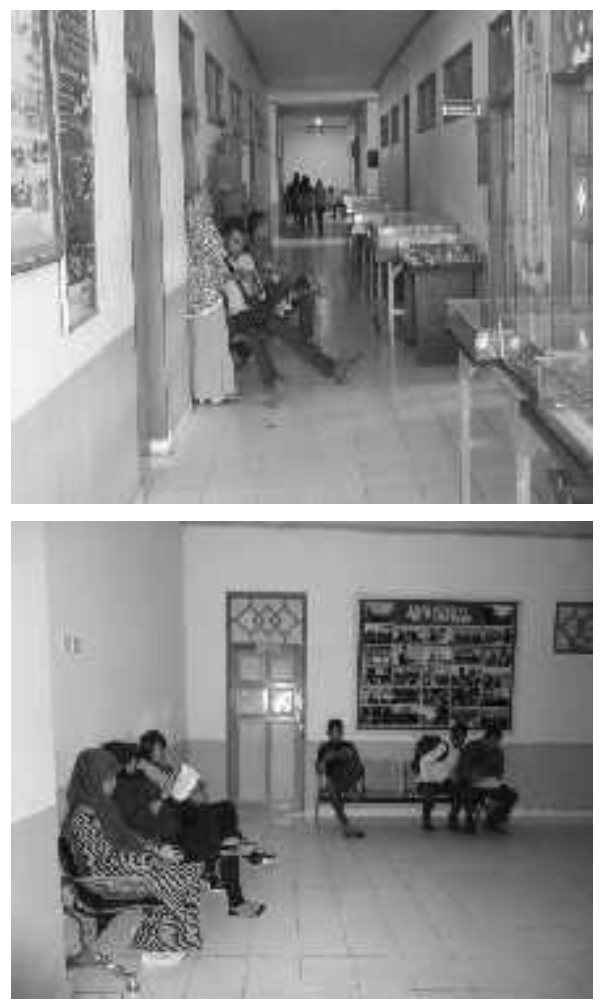

Gambar. 2 ruang personal di kampus unisan

\section{b. Ruang Privasi (privacy space)}

Privasi adalah kemampuan seseorang atau sekelompok orang untuk menggendalikan interaksi mereka dengan orang lain, privasi memiliki kemampuan untuk mengontrol terbuka atau tertutupnya jalur komunikasi (Laurens, 2004).

Privasi (privacy), sebagai usaha untuk menggoptimalkan pemenuhan kebutuhan sosial manusia. Privasi adalah keinginan atau kecenderungan pada diri seseorang untuk tidak diganggu kesendiriannya. Holahan membuat alat untuk mengukur kadar dan mengetahui jenis privasi dan ia mendapatkan bahwa ada enam jenis privasi, terbagi dalam dua golongan (Laurens, 2004) yaitu :

Pada hasil pengamatan terlihat, baik seseorang maupun sekelompok orang lebih mudah memperoleh privasi dengan menempati area tertentu. contoh dari privasi yang terjadi di Ruang Publik kampus Unisan adalah penggunaan area tangga sebagai tempat duduk, maupun area sekitar tangga sebagai tempat duduk sambil menunggu jam kuliah masuk.
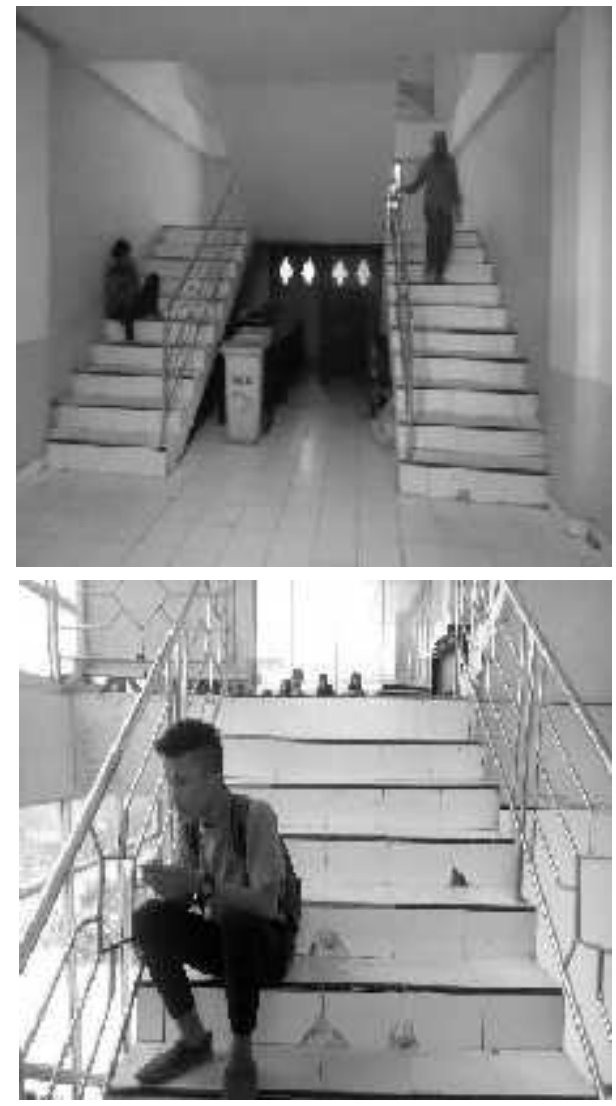

Gambar. 3 ruang Privasi di kampus unisan

\section{c. Teritorialitas (territoriality)}

Teritorialitas sebagai sesuatu yang berkaitan dengan ruang fisik, tanda, kepemilikan, pertahanan, penggunaan yang eksklusif, personalisasi, dan identitas. Teritori dapat dikatakan sebagai 
perwujudan dari privasi seseorang, dalam perancangan ruang-ruang arsitektural, teritori dapat dibedakan melalui batas nyata seperti dinding, pintu, ataupun batas simbolik (artikulasi bentuk, penggunaan material, permainan warna dan cahaya) sehingga dapat terbentuk suatu tatanan yang utuh (Laurens, 2004).

Teritorialitas

(territoriality),

yaitu

kecenderungan untuk menguasai daerah yang lebih luas bagi penggunaan oleh seseorang atau kelompok pemakai atau bagi fungsi tertentu. Julian Edney dalam mendefinisikan teritorialitas sebagai sesuatu yang berkaitan dengan ruang fisik, tanda, kepemilikan, pertahanan, penggunaan yang eksklusif, personalisasi, dan identitas. Termasuk di dalamnya dominasi, control, konflik, keamanan, gugatan akan sesuatu, dan pertahanan teritori berarti wilayah atau daerah dan teritorialitas adalah wilayah yang dianggap sudah menjadi hak seseorang (Laurens, 2004).

Jenis teritori yang ada pada Ruang Terbuka kampus unisan adalah jenis teritori publik yang mana area ini dapat digunakan atau dimasuki oleh siapapun. Teritori yang sangat jelas pada penggunaan tempat duduk yang di gunakan oleh mahasiswa seangkatan atau penggunaan area tangga sebagai tempat duduk bersama.
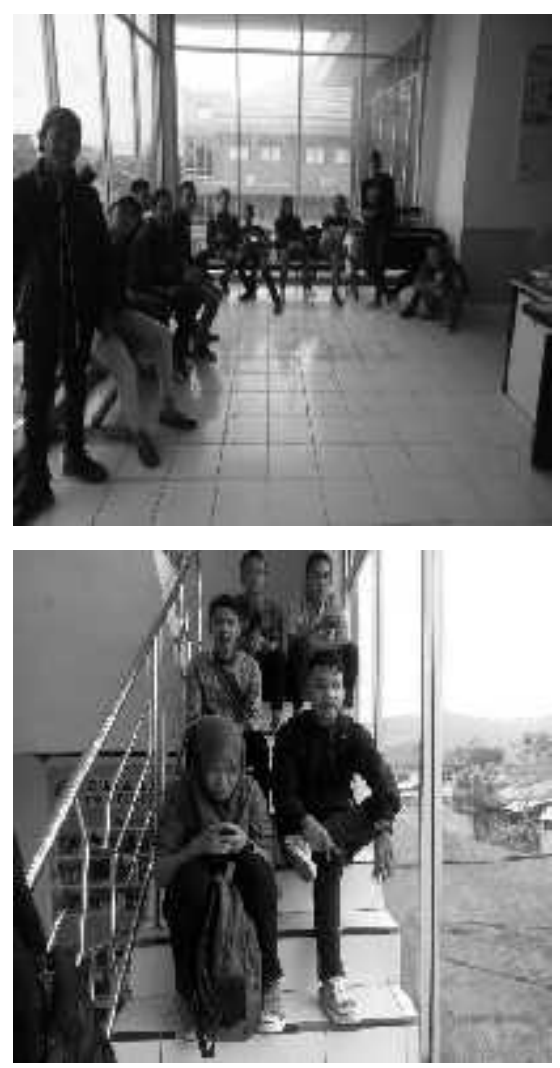

Gambar. 4 ruang Teritorialitas di kampus unisan

\subsection{Perubahan Setting Ruang Terbuka Kampus Unisan}

Adanya perubahan setting ruang kampus unisan merupakan temuan secara umum tentang analisis pola pemanfaatan dan pola aktifitas pengguna ruang terbuka di kampus Unisan berdasarkan satuan waktu berdasar satuan hari kerja, sedangkan untuk faktor analisis pada waktu libur dalam pembentukan pola pemanfaatan dan aktifitas terlihat tidak di pergunakan berdasar satuan waktu,dimana terlihat pada ruang kampus kosong.

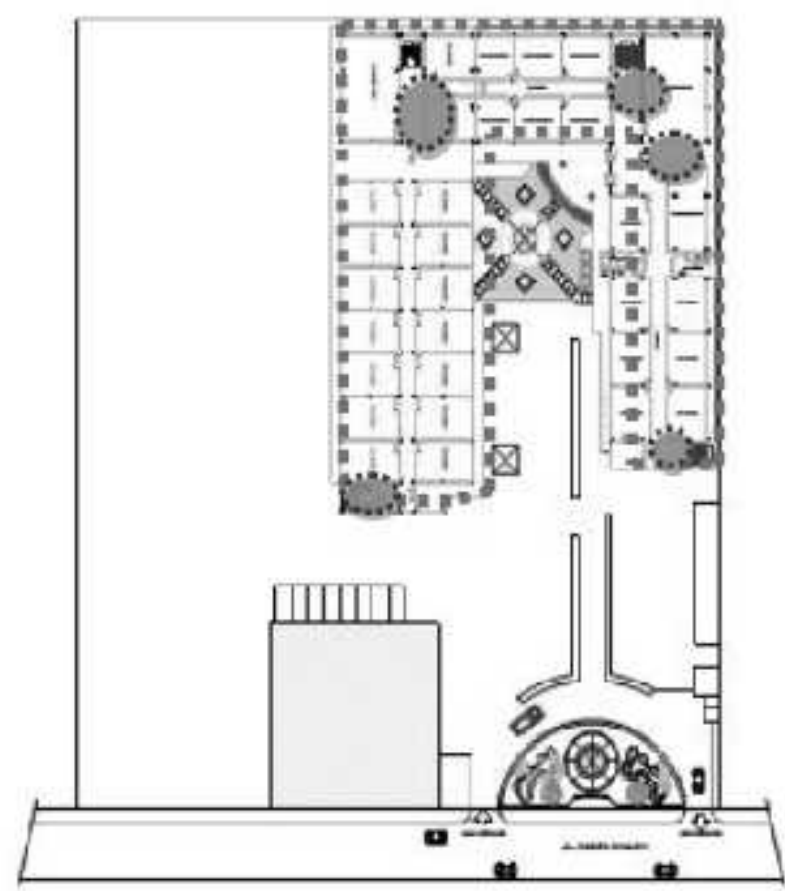

Gambar. 5 area perubahan setting di kampus

\section{PENUTUP}

\subsection{Kesimpulan}

Perubahan setting ruang terbuka yang ada di kampus Unisan bergantung pada Pola perilaku mahasiswa yang menggunakan ruang terbuka publik kampus Unisan yang umumnya berupa aktivitas yang berulang tiap harinya yaitu duduk-duduk/ berbincang-bincang dengan sesama.

Aktifitas yang terjadi lebih banyak di gunakan pada pagi sampai malam hari, hal ini rata-rata aktivitas yang terjadi adalah aktivitas duduk-/gobrol sambil menunggu jam kuliah masuk, Untuk mendapatkan pemanfaatan ruang terbuka yang lebih maksimal diperlukan penambahan tempat duduk untuk pengguna ruang serta perbaikan, perawatan sarana dan prasarana pada area ruang publik kampus yang bisa menunjang aktifitas pengguna ruang.

\subsection{Saran}

Berdasarkan hasil penelitian dan kesimpulan maka saran yang dapat penulis berikan yaitu :

a. Rata-rata mahasiswa menghabiskan waktu di ruang terbuka hanya di area ruang yang memiliki tempat duduk serta lebih banyak mahasiswa menggunakan area tangga, alasan menggunakan Area tangga karena kurangnya tempat duduk 
yang tersediah saat menunggu jam perkulihaan, sehingga perlunya penambahan sarana duduk.

b. Dalam melakukan penelitian berikutnya, yang berkaitan dengan pemanfaatan ruang terbuka, selain meninjau dari pelaku dan aktivitas perlu meninjau waktu penelitian lebih spesifik lagi, karena perilaku pada pagi hari sampai malam hari, berbeda-beda sesuai dengan aktivitas pengguna.

\section{DAFTAR PUSTAKA}

Azmy. (2012). Pemanfatan Fungsi Taman Ayam Daya Kota Makassar, Prosiding. Hasil Penelitian Fakultas Teknik. Universitas Hasanuddin. Makassar.

Faraby. (2010). Perilaku Spasial Anak Jalanan di Yogyakarta, Universitas Gadjah Mada, Yogyakarta, Jurnal Arsitektur dan Perencanaan, Volume 4, No. 2.

Haryanti, Dini Tri. 2008, Kajian Pola Pemanfaatan Ruang Terbuka Publik Kawasan Bundaran Simpang Lima Semarang, Magister Teknik Pembangunan Wilayah Dan Kota, Universitas Diponegoro, Semarang.

Haryadi. Dan B, Setiawan. 2010. Arsitektur, Lingkungan dan Perilaku, Gadjah Mada University press, Yogyakarta.

Laurens. (2004). Arsitektur Dan Perilaku Manusia, PT Gramedia widiasarana Indonesia, Surabaya.

Laurens. (2004). Arsitektur Dan Perilaku Manusia, PT Gramedia widiasarana Indonesia, Surabaya.

Saragih. (2010). Mekanisme Pencapaian Privasi Mahasiswa Pada Pondokan Tipe Asrama Perorangan di Kampung Kota Iromejan dan Samirono, Universitas Gadjah Mada, Yogyakarta, Jurnal Arsitektur dan Perencanaan, Volume 4, No. 2.

Sunaryo. (2010). Perubahan Setting Ruang dan Pola Aktivitas Publik di Ruang Terbuka Kampus UGM, Humanisme, Arsitektur Dan Perencanaan, Universitas Gadjah Mada. Yogyakarta, Seminar Nasional Riset Arsitektur dan Perencanaan (Serap) 1.

Whyte. (1980). The Social Life of Small Urban Spaces. The Conservation Foundation. Washington D.C. 